\title{
Strategies to Validate the Use of Plants as Antimalarial
}

\author{
Milena Cristina Martins da Silva ${ }^{1}$, José Mário Veloso Peres ${ }^{2}$, Marinete Marins Póvoa ${ }^{2}$, Giselle Maria Rachid \\ Viana $^{2}$ and Maria Fâni Dolabela ${ }^{1 *}$ \\ ${ }^{1}$ Postgraduate program, Pharmaceutical Sciences, Brazil
}

${ }^{2}$ Section of Parasitology, Instituto Evandro Chagas, Brazil

Submission: July 27, 2017; Published: August 07,2017

*Corresponding author: Maria Fâni Dolabela, Postgraduate program in Pharmaceutical Sciences- PPGCF/UFPA/BRA, Brazil, Tel: +55 91 32018828; Email: fanidolabela20@gmail.com

\begin{abstract}
Due to high number of people at risk of malaria, and the emergence of multidrug-resistant strains of Plasmodium, the searching for alternative treatments, and isolation of antimalarial compounds are urgente.Folk medicine have been used to treat malaria for thousand years. However, some studies have shown absence of antiplasmodic activity of plants popularly used for treatment. This lack of agreement between the popular use and laboratory tests requires the application of adequate methods of analysis to prove the efficacy and safety of medicinal plants, andto determine their potential as complementary therapy or source of isolated compounds as antimalarial drug. This review compared some methods for evaluating antiplasmodial activity Through the analysis of the methods, the most efficient way to evaluate the activity of plants used in traditional medicine is use rapid tests as screening, then use microtest to test promising sample, and finally, use in vitro methods to assess parasitemia in rodents and clinical aspects.
\end{abstract}

Keywords: Alternative malaria treatments; Traditional medicine; Methods for searching new drugs

\section{Introduction}

Malaria is a parasitic disease from tropical regions caused by species of Plasmodium, Plasmodium vivax, P. falciparum, P. malariae, P. ovale and P. Knowlesi in humans, transmitted by mosquitoes of genus Anopheles. As a public health concern,malaria presented 212 million new cases and 429,000 deaths in 2015, and it was considered as endemic in 91 countries in 2016 [1]. The emergence and rapid spread of multidrug-resistant strains of Plasmodium, has been identified as the major cause of control failure. Recent evidence suggests parasites resistance to the nearly all available drugs including the newest ones [2].

Since billionpeople are still at risk of malaria, and emergence of multidrug-resistant strains of Plasmodium represent a major problem for treatment, even in combination therapy schemes [3-5], the searching for alternative treatments, and isolation of affordable and efficient antimalarial compounds are urgent.

Folk medicine have been used to treat malaria for thousand years. The traditional use of plants led to the discovery of the two main groups (artemisinin and quinine derivatives) of modern antimalarial drugs, after the physician Francesco Torti began using high doses of the powdered bark of cinchona in patients which presented signs of malarial fevers, resulting in quinine and 30 more alkaloids isolation in 1820 by Pelletier and Caventou, based on records of South American natives writtenfirst by Juan Fragoso and Nicolas Monardes [6-9].

The use of medicinal plants to treat this disease is common in many countries, especially in regions with low economic development and dificult access where health services are limited, and plants are a sustainable source of treatment. In Zimbabwe, for example, due to the high use of traditional plant-based medicines to combat malaria, some surveys have been made to document how the malaria diagnose is made by traditional healers, and the mode of preparation and administration of plants for malaria prevention and treatment [10]. This initiative not only increases and improves the people participation in the fight against malaria, but also, preserves local traditions and knowledge. Brasilian natives also use plants to treat fever and malaria manly in rural areas or inside the forest, in the heart of the Amazon. Several studies have reported the exotic and native species used in Brazil totreatthis condition [11-15]. 
However, several studies have also demonstrated that the popular use of plants is not always justified in the laboratory. In Mozambique,from 58 extracts tested as antimalarial, only two showed significant activity (IC50 $<5 \mu \mathrm{g} / \mathrm{mL}$ ) [16]. In Cuba, another studyevaluated the activity of 14 plant species, in which, the use of only two was validated [17]. This lack of agreement between the popular use and laboratory tests requires the application of adequate methods of analysis in order to guarantee high reliability of the results, and prove the efficacy and safety of medicinal plants used as complementary tharapy or isolated compound as drug treatment as well.

The choice of the appropriate method of analysis should be made taking into account the number of samples, the feasibility of the test (equipment, ability of the microscopist and physical lab conditions), and the particularities of each method. This review aimed to compare some methods for evaluating antiplasmodial activity highlighting their advantages and disadvantages in order to guide the researchers on the choice of the appropriate method.

\section{Methods to evaluate the antiplasmodial activityof promising drugs}

There are several methods to evaluate the activity against the Plasmodium. The general objective of these methods isassess the parasitemia aftertreatment with the drug under analysis. The most common ways to evaluate this is through in vivo and in vitro essayor chemical tests which use hypoxanthineor other substances as markers.

For choosingthe method correctly, it is important to keep in mind that the Plasmodium is a selective species, it means, species that infect humans do not infect rodents. Plasmodium berghei is often used for the study of human malaria because of its ability to infect rodents and relative ease of genetic engineering [18]. In this context, the main disadvantages of in vivo studies are: genetic differences between the parasites used in the experiment, and the parasites that infect humans, and the need for a greater quantity of test samples than in vitro test, which may limit plant metabolites tests due to their difficult extraction and the low yield; As an advantage, in vivo studies have the possibility of evaluating, besides the reduction of parasitemia, whether the test sample interferes with disease clinical aspects.

In vitro studies are widely used for plant extracts, fractions and pure substances screening, and has the advantage of using $P$. falciparum without high amount of samples. The main techniques for evaluating antimalarial activity in vitro are: microtest, incorporation of labeled hypoxanthine, Histidine-Rich Protein 2 (HRP2) and Plasmodium Lactate Dehydrogenase (pLDH). In the microtest, the antiplasmodic activity can be evaluated after $24 \mathrm{~h}$ or $72 \mathrm{~h}$ of treatment to assess the 1st or 2 nd schizogony inhibition [19]. However, this method requires good microscopy ability, and the workload is very large due to the number of microscopy slides, about 32-80 slides for each sample tested. This technique has also some advantages: it allows to evaluate the parasites morphology and the parasitemia; In general, if the procedures are done properly, there is a good repeatability of the results.

The hypoxanthine test came to reduce the microtest workload. In that test, the parasites are exposed to a radioactive hypoxanthine that is incorporated by them, and evaluated in betascintillator [20]. Undoubtedly, this method is very adequated, but it runs into some limitations: the need for a license from the National Nuclear Energy Commission to purchase the radioactive material, and homologate the room where the test will be done.

The pLDH-based testcould be used as a quick and easy strategy for the screening of active substancesby the identification of antigensof malaria parasites. This method is currently used to detect parasites in circulation; however, a recente study revealed an alternative approach:the enumeration of total parasite bio-burden by bio-luminescent through commercial ELISA humanparasite lactate dehydrogenase ( $\mathrm{pLDH})$ detection kit in murine malaria models [21].

Other altenative is theHRP2 that implies in the detection of malaria parasites' histidine on the red blood cells. A potential problem for HRP2-based assays isthe persistence of detectable antigen for up to severalweeks after parasites eradication. The advantage of HRP2 and pLDH-based teststhese testsare the absence of microscopy that requires a wellmaintainedequipment, significanttechnical skills, good-quality reagents and a considerable number of slides. Disadvantages are that test results are qualitative and do notprovide prognostic information, such as parasite staging. Therefore, these tests, considered as the fast ones, can be used as screening when the quantity of samples are large and require a lot of work if all the samples are tested through the microtest.

Through the analysis of all these methods, the most efficient way to evaluate the activity of plants used in traditional medicine for malaria treatment would be better developed bythe following steps: Choice of in vitro method $\rightarrow$ active or inactive $\rightarrow$ perform in vivo study using $P$. berghei (to determine parasitemia, clinical aspects)

\section{Conclusion}

In Conclusion, we suggest, based on the advantages and disadvantages presented in this analysis, that if the number of test samples is reduced the microtest would be a better option. When the quantity of samples are large, the rapid tests would be used as screening before microtest because they do not require extensive training, and many or wellmaintainedequipment, besides reducing the amount of work. Lastly, methods in vitro using P. berghei should be used to assess parasitemia in rodents and clinical aspects

\section{Authors Contribution}

MCMS was the sole-principle investigator of study. JMVP, MMP, GMRV eMFD performed editorial guidance and research 
methodology analysis and MFDwas responsible for submitting the manuscript.

\section{References}

1. WHO (2016) Malaria Report, World Health Organization, Geneva, Switzerland.

2. WHO (2001) Drug resistance in malaria, Bloland P, World Health Oragnization, USA.

3. Noedl H, Se Y, Schaecher K, Smith BL, Socheat D, Fukuda MM, et al. (2008) Evidence of artemisinin-resistant malaria in western Cambodia. N Engl J Med 359(24): 2619-2620.

4. Silva JR, Ramos DS, Machado M, Moura DF, Neto Z, et al. (2011) A review of antimalarial plants used in traditional medicine in communities in Portuguese-speaking countries: Brazil, Mozambique, Cape Verde, Guinea-Bissau, São Tomé and Príncipe and Angola. Mem Inst Oswaldo Cruz 106(Suppl I): 142-158.

5. Ajayi NA, Ukwaja KN (2013) Possible artemisinin-based combination therapy-resistant malaria in Nigeria: a report of three cases. Rev Soc Bras Med Trop 46(4): 525-527.

6. Jarcho S, Torti F (1993) Quinine's predecessor : Francesco Torti and the early history ofcinchona. Med Hist 38(3).

7. Bruneton J (1995) Pharmacognosy phytochemistry medicinal plants. Paris, Lavoisier.

8. Huxtable RJ, Schwarz SKW (2001) The isolation of morphine--first principles in science and ethics. Mol Interv 1(4): 189-191.

9. Spelman K, Medicinal Plants for Malaria: A realistic use of herbals?

10. Ngarivhume T, Van't Klooster CIEA, Jong JTVM, Westhuizen JHV (2015) Medicinal plants used by traditional healers for the treatment of malaria in Chipinge district in Zimbabwe. J Ethnopharmacol 159: 22437.

11. Milliken W (1997) Traditional anti-malarial medicine in Roraima, Brazil. Economic Botany 51(3): 212-237.
12. Oliveira FQ Junqueira RG, Stehmann JR, Brandão MGL (2003) Potencial das plantas medicinais como fonte de novos antimaláricos: espécies indicadas na bibliografia etnomédica brasileira. Rev Bras Plantas Med 5(2): 23-31.

13. Botsaris AS (2007) Plants used traditionally to treat malaria in Brazil: the archives of Flora Medicinal. J Ethnobiol Ethnomed 3: 18.

14. Dolabela MF, Oliveira SG, Nascimento JM, Peres JM, Wagner H, et al. (2008) In vitro antiplasmodial activity of extract and constituents from Esenbeckia febrifuga, a plant traditionally used to treat malaria in the Brazilian Amazon. Phytomedicine 15(5): 367-372.

15. Mariath IR, Falcão HS, Barbosa-Filho JM, Sousa LCF, Tomaz ACA, et al. (2009) Plants of the American continent with antimalarial activity. Rev Bras Farmacogn 19(1): 158-192.

16. Ramalhete C, Lopes D, Mulhovo S, Rosário VE, Ferreira MJU, et al (2008) Antimalarial activity of some plants traditionally used in Mozambique. Workshop Plantas Medicinais e Fitoterapêuticas nos Trópicos IICT/CCCM.

17. Valdés AF, Martínez JM, Lizama RS, Gaitén YG, Rodríguez DA, Payro JA, et al. (2010) In vitro antimalarial activity and cytotoxicity of some selected Cuban medicinal plants. Rev Inst Med Trop 52(4): 197-201.

18. Nussenzweig R, Herman R, Vanderberg J, Yoeli M, Most H, et al. (1966) Studies on sporozoite-induced infections of rodent malaria.3. Am J Trop Med Hyg 15(5): 684-689.

19. WHO (2001) In vitro micro-test (Mark III) for the assessment of the response of Plasmodium falciparum to chloroquine, mefloquine, quinine, amodiaquine, sulfadoxine/pyrimethamine and artemisinin, World Health Organization, Geneva Switzerland.

20. Kalra B, Chawla S, Gupta P, Valecha N (2006) Screening of antimalarial drugs: an overview. Indian J Pharmacol 38(1): 5-12

21. De SL, Stanisic DI, Rivera F, Batzloff MR, Engwerda C, Good MF, et al. (2016) Plasmodium berghei bio-burden correlates with parasite lactate dehydrogenase:application to murine Plasmodium diagnostics. Malar J 15: 3.

Your next submission with Juniper Publishers
will reach you the below assets
- Quality Editorial service
- Swift Peer Review
- Reprints availability
- E-prints Service
- Manuscript Podcast for convenient understanding
- Global attainment for your research
- Manuscript accessibility in different formats
( Pdf, E-pub, Full Text, Audio)
- Unceasing customer service
Track the below URL for one-step submission
https://juniperpublishers.com/online-submission.php

